\title{
The impact of Pandita training on the skill of performing Buddhist rituals
}

\section{Budiyanto ${ }^{1 *}$, Taridi $^{2}$}

1,2Buddhist Education, Jinarakkhita Buddhist College, Lampung, Indonesia

\begin{abstract}
This study aims to explore the impact of pandita training on the skill of performing Buddhist rituals. Rituals or ceremonial acts are not inherently religious. Rituals play a role in relieving social pressures and strengthening the collective bonds of a group. Rituals are performed in various forms, including the tradition of lighting candles or incense, wearing certain clothes, and sitting, standing, or kneeling during praying. The most common of all rituals is the initiation ceremony which marks a stage in the human life cycle. The type of research used in this study is descriptive quantitative research. The data analysis technique was carried out in several stages, including the following: 1) validity test technique to determine the validity of the moment item, using product moment analysis; 2) the instrument's reliability test uses the Alpha formula; 3) simple regression model is chosen to measure the effect of religious training variable $(\mathrm{X})$ on skills to lead religious activities (Y). Based on data analysis, it can be concluded that the training of Pandita can improve the skills of Pandita in performing rituals.
\end{abstract}

ARTICLE INFO

Keywords:

Training pandita, skill, Buddhist ritual

\section{Article History:}

Received: Dec 14 $4^{\text {th }}, 2021$

Revised: Dec 28th, 2021

Accepted: Dec 29th 2021

Published: Dec 30th 2021

How to Cite in APA Style:

Budiyanto \& Taridi. (2021).

The impact of Pandita training on the skill of performing Buddhist rituals. Smaratungga: Journal of Education and Buddhist Studies, 1(2), 50-55. doi: $10.53417 /$ sjebs.v1i2.57

\section{Introduction}

Religious ritual activities such as praying privately or visiting places that are considered sacred if carried out in broad scope, celebrating holidays, and so on, have the effect of giving teachings to all adherents (Kreinath, 2005), as the adherents feel that these activities can form morals and control mind and body by performing rituals (Kusalanan et al., 2020). Rituals consist of symbolic actions representing religious meaning (Widodo, 2020; Yasa, 2020). Rituals actualize symbols into sacred actions. Through rituals, symbols are lived and celebrated. The role of ritual for religion and culture is to remember the past, preserve, and convey a society's foundation (Ashsubli, 2018). Participants are identified with a sacred past, thus preserving tradition as they redefine the principles a group lives and plays a role. In this case, ritual plays a vital role in uniting all adherents.

*Corresponding author: budiyanto.budiyanto@sekha.kemenag.go.id

Published by Center of Research and Publication of Smaratungga Buddhist Collage

This is an open access article under the CC BY-NC 4.0 (https://creativecommons.org/licenses/by-nc/4.0/) https://doi.org/10.53417/sjebs.v1i2.57 
Rituals are remarkably effective in building the religious identity of a particular religion. All activities can be conducted as long as a person or group leads them. On the other hand, in a Buddhist society, a community of lay people is allowed to hold ceremonies conducted by monks or nuns even though it is said that rituals or ceremonial acts are not religion. However, rituals play a role in freeing social pressures and strengthening the collective bonds of a group (Pemaratana, 2020).

Furthermore, rituals provide a way to mark momentous events and reduce social disruption and the individual suffering from crises such as death. Like other aspects of culture, rituals are not based on instinct, and hence they must be passed down from one generation to the next to keep them existing. Rituals are performed in various forms, including the tradition of lighting candles or incense, wearing certain clothes, and sitting, standing, or kneeling during prayer. The most common of all rituals is the initiation ceremony which marks a stage in the human life cycle. The transfer ceremony is a social ceremony that marks the transition of members of a group from one crucial life stage to the next stage (Berkwitz, 2012).

The ritual will run smoothly if a person or group helps a person called pandita. According to the Indonesian dictionary, a pandita is a religious leader. The role of pandita in Buddhist society is a model for Buddhists in conveying Buddha's teachings with the existence of a sangha or a community of monks or nuns (A.III.178). Pandita is a person who acts as a leader to guide people to understand Dhamma. As a leader, pandita must have the following criteria: 1) guaranteeing existence, 2 ) bringing prosperity and peace and reducing obstacles, 3 ) controlled thoughts, words, and actions, 4) protecting noble persons, 5) eliminating existing mental impurities, 6) preventing the emergence of new defilements, 7) explaining the Dhamma well, 8) increasing the faith of Dhamma adherents, and 9) establishing discipline (A. V.70).

Leadership is an activity that influences individuals to work together to achieve the same goal (Mukti, 2020:26). In achieving the goals, a leader must have the criteria of a leader. A good leader is a democratic leader. A democratic leader can be a humanist in leading a particular organization or management. Besides having the capacity and credibility to lead, ideally, a leader must have good morals and ethics that can be developed later to realize a goal. The Buddha allows his disciples to analyze and practice the teachings according to their abilities (A.I.188).

One thing that a priest must understand is religious ritual activities. Therefore, it is necessary to understand the procedures for the ceremony. Concerning the definition, the ceremony is an embodiment of faith and piety and is an attitude that must be considered by every Buddhist (Abeysekara, 2019). The form of faith and piety is conducted by carrying out worship. This expression of respect and devotion makes Buddhists perform worship. Buddhism defines worship as the reverence and practice of the Buddha's teachings. This embodies belief (saddha) in the Triratna. worship is a form of ceremony that aims to give strength to practitioners and encourage concrete actions, and hence it brings blessings, both for ourselves and other beings (Mukti, 2020). In other words, one who does bhakti practices the Dhamma.

"In this world, to obtain merits, sacrifices or offerings made by a person for a hundred years is not equivalent to a quarter of respect for people who live righteously" (Dh.106-108). The verse reveals that someone certainly does respect 
not because he hopes to get blessings from respected people, but the results are used as inspiration to practice the precepts (sīla). Precepts are behavior carried out not only in outward form but also in inner form. All actions based on awareness and inner sincerity will get good results. "The one who is conscious is wise, and the conscious one lives in happiness" (S.I.208). Implementation of precepts is needed to form norms, ethics, and rules of good behavior in a society. The ideal is to weaken the evil deeds done through thought, speech, and action. Without real effort, emotions will not be under the control of desire. Buddhist training aims to master emotions in numerous ways.

The first step: carrying out the five precepts (pañcasīla) will help control the rude form of emotional lust as the basis, with self-awareness and sincerity as the behavioral principles. The second step is to train the mind to control emotions when emotions begin with awareness. The Buddha advised his disciples to always do good things by carrying out the precepts because, with good precepts, the human life in the next life can be maintained in a better condition (A.I.49). Daily practice of precepts will help to control negative emotions and dirty lust, such as avoiding killing, avoiding theft, avoiding immorality, avoiding lie, and abstaining from drinking. Implementing the precepts has a good impact as a protector and increases faith and piety.

\section{Method}

The type of research used in this research is descriptive quantitative research and aims to test the hypotheses of the theories that have been discussed in the previous section. Descriptive research is a type of research that provides an overview or description of a situation as clearly as possible without any treatment of the object under study (Sugiyono, 2019). Descriptive research aims to create a systematic, factual, and accurate description, picture, or depiction of the facts, characteristics, and relationships between the investigated phenomena.

The sample is part of the number and characteristics possessed by the population (Sugiyono, 2016). The sample in this study was 100 people taken from 13 viharas, using the purposive sampling technique. This research was conducted in Pesawaran-Lampung from September 2019 to December 2019. Questionnaires collected the data collection technique from 100 people. The data analysis technique was carried out in several stages, including the following: 1) Validity test technique to determine the validity of the product-moment, then using product moment analysis. 2) Reliability test of the instrument using the Alpha formula. 3) Simple regression model to measure the effect of religious training variable (X) on skills to lead religious activities (Y).

\section{Findings}

Because the research location is considerable between Bandar Lampung and Pesawaran, the instrument test took respondents from several nearby temples. The selected respondents were monastics with priests who must have attended priestly training. Respondents for the instrument trial were 20 people. The respondents were categorized as adults; thus, they could assess the priests. Based on the trial of the priest training instrument and ritual leadership skills, there were obtained 
information from the 60 questions, there were 55 valid questions, and five items were invalid, precisely questions of numbers $3,15,41,46$, and 51 . From 55 items declared as valid, the highest correlation index of 0.853 on item no. 56 was obtained. The complete instrument validity test results can be seen in the appendix of the validity test on page 73 . From the test results of the 60 available items, the invalid items are corrected while considering the quality and content of the instrument. Furthermore, after the invalid items are corrected, they are combined with valid items and used to assess the priests who have attended priest training.

After analyzing the validity of the data, the researchers tested the reliability of the data obtained from distributing questionnaires to research subjects. The results of the instrument trial with 60 items were conducted on 20 people. Measurement of reliability used an Analysis Scale (Alpha) 0.747. These results indicate that the priest training instrument and ritual leadership skills are reliable with a relatively high criterion of 0.747 . It can be concluded that the instrument used in the study has met the requirements of good validity and reliability; thus, it can be used in research. The last test was a simple regression test by applying SPPS 17. The results can be seen in the table below.

Table 1. X-Y Regression Equation Output (Coefficients)

Coefficients $^{\mathrm{s}}$

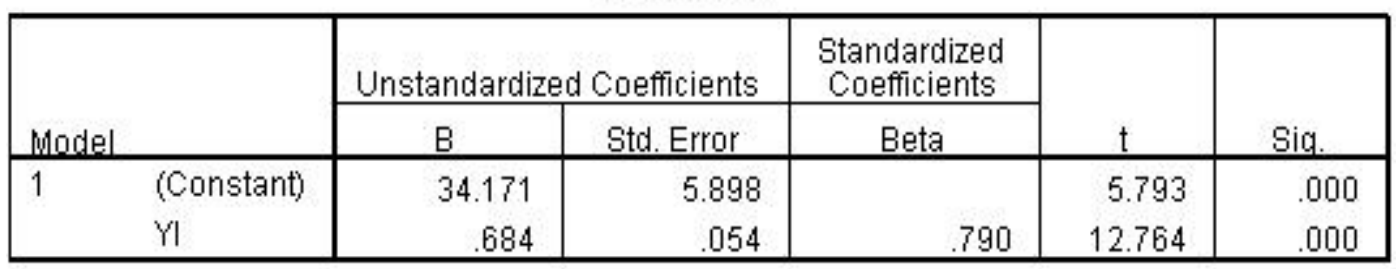

a. Dependent Variable: $X$

Based on the output results in Table 1 , the regression equation $\mathrm{y}=$ $34.171+0.684$. $\mathrm{X}$ is obtained. Furthermore, to test the values of $\mathrm{a}$ and $\mathrm{b}$ and determine whether the hypothesis is accepted or rejected is by reading the ANOVA table. It can be seen on the table that the value of $\mathrm{F}=110.337$ and $\operatorname{sig}=0.00$ so that it does not need to be matched with table $\mathrm{F}$ because SPSS has facilitated it with a significant value. The interpretation of the results obtained is sig $0.000=0 \%<5 \%$, meaning that $\mathrm{H} 0$ is rejected and $\mathrm{H} 1$ is accepted. This means that priest training and ritual leadership skills have a linear relationship or priest training affects ritual leadership skills. Furthermore, the analysis can be seen from the value of the coefficient of determination $\mathrm{R}^{2}$.

Table 2 Output Anova x1-y

ANONA $^{\text {b }}$

\begin{tabular}{|ll|r|r|r|r|r|}
\hline Model & & \multicolumn{1}{c|}{$\begin{array}{c}\text { Sum of } \\
\text { Squares }\end{array}$} & df & Mean Square & F & \multicolumn{1}{c|}{ Sig. } \\
\hline 1 & Regression & 1832.408 & 1 & 1832.408 & 110.337 & $.000^{\circ}$ \\
& Residual & 647.689 & 39 & 16.607 & & \\
& Total & 2480.098 & 40 & & & \\
\hline
\end{tabular}

a. Predictors: (Constant), k_emosional_x1

b. Dependent Variable: Prestasi_Y 
Table 3 Output Coefficient of Determination Value $\mathrm{R}^{2}$ Square $\mathrm{X}-\mathrm{Y}$

\section{Model Summary}

\begin{tabular}{|l|l|r|r|r|}
\hline $\begin{array}{l}\text { Mode } \\
\perp\end{array}$ & $\mathrm{R}$ & $\mathrm{R}$ Square & $\begin{array}{c}\text { Adjusted R } \\
\text { Square }\end{array}$ & $\begin{array}{c}\text { Std. Error of } \\
\text { the Estimate }\end{array}$ \\
\hline 1 & $.790^{\mathrm{a}}$ & .624 & .621 & 9.172 \\
\hline
\end{tabular}

a. Predictors: (Constant), Yl

The output results (Table 3) show the value of $\mathrm{R}$ square or $\mathrm{R}^{2}=0.624=62.4 \%$. This value indicates that priesthood training affects ritual leadership skills by $62.4 \%$, and other factors influence as much as $27.6 \%$.

\section{Discussion}

The results of the descriptive analysis show that the analysis of each instrument has a good score. It means that all pandita or community groups in Pesawaran can be initiated as a pandita. This can be seen from the indicators regarding the nurture of priests. One of them is an indicator of empathy, in line with what the Buddha said in the Mahāparinibbāna Sutta (D.II.72) that a wise person is the one who has a concern. This concern is undoubtedly formed from a sense of empathy for the community. Therefore, empathy is essential to building a society in the spiritual field.

In addition to empathy, the indicator of attention also has a reasonably high value. Empathy is an essential aspect of the skills of leading religious rituals. With the attention of a priest, he can provide advice and guidance to the people in carrying out ritual activities. Furthermore, descriptive analysis on the indicator variables of skills to lead religious rituals shows that priests have high abilities. According to the adjustment indicators, the results show that priests can adjust to religious ritual activities. This means that the adjustment of ritual leadership skills is significant. Because with that adjustment, the priests will be able to lead the ritual wisely. Wisdom will surely make a good contribution in the implementation of religious rituals, with the discernment that the implementation of religious activities will run as expected; thus, what has been done in fostering clerical activities has a significant contribution in developing Buddha dharma. Hence, it can be said that the training for priests in the districts positively influences the development of Buddhists.

It seems that the training of Pandita and the skills of leading religious rituals are critical in developing the Buddha Dharma. This can be seen from the results of the analysis. It can be concluded that the training of priests is essential in building the competence of priests in helping the sangha. The importance of these activities can be seen from the test results of the effect of religious training on the skills of leading religious rituals.

Based on the analysis results, the error value of $5 \%$ shows a significance value of $0.00 \%$, which is less than $5 \%$. It means that priesthood training affects the skills of leading religious rituals.

The strong influence can be seen from the R square value of 0.624 or $62.4 \%$ and $37.6 \%$, influenced by factors other than undergraduate education. This means that the training has a significant influence, and it can be stated that the implementation of a good ritual can run well if there is conducive training. 


\section{Conclusion}

The present study aims to explore the impact of pandita training on the skill of performing Buddhist rituals. The result depicted that the pandita training positively affects the skills to lead ritual activities. Apart from the compelling results, this study acknowledges that the research participants could not represent the whole population of all panditas in Indonesia. Therefore, further inquiries are essential to be conducted by involving a more significant number of participants and various instruments of data collection, in addition to the interviews that had been used in this study.

\section{References}

Abeysekara, A. (2019). Protestant Buddhism and 'influence': the temporality of a concept. Qui Parle. 28(1): 1-75.

Ashsubli, M. (2018). Ritual budaya mandi Safar di Desa Tanjung Punak Pulau Rupat Kabupaten Bengkalis, Riau. Journal of Islam and Plurality. 3(1), 84-101.

Berkwitz, S. (2012). "The Ethics of Devotion in the Sinhala Thupawamsa." In Embedded Languages: Studies of Sri Lankan and Buddhist Cultures, edited by Carol S. Anderson et al. Colombo: Godage International Publishers.

Kreinath, J. (2005). Ritual: Theoretical issues in the study of religion. Revista de Estudos da Religião. Pp. 100-107.

Kusalanan, S. dkk. (2020). Makna simbolik Ritual Selamatan Methik Pari dalam pandangan Agama Buddha di Desa Gembongan Kecamatan Ponggok Kabupaten Blitar. Jurnal Pariwisata dan Budaya, 1(1), 32-44.

Majjhima Nikaya (The Middle Length Sayings) Vol. I. Trans. Horner. I.B. (1989). London. Pali Teks Society.

Majjhima Nikaya (The Middle Length Sayings) Vol. II. Trans. Horner. I.B. (1989). London. Pali Teks Society.

Majjhima Nikaya (The Middle Length Sayings) Vol. III. Trans. Horner. I.B. (1989). London. Pali Teks Society.

Mukti, K. W. 2020. Wacana Buddha-Dhamma. Jakarta: Karaniya.

Pemaratana, S. (2020). Reviving the Buddha: The use of the devotional ritual of Buddha-Vandanā in the modernization of Buddhism in colonial Sri Lanka. Journal of Global Buddhism, 21, 29-50. doi: 10.5281/zenodo.4030979

Sugiyono. 2016. Metode Penelitian dan Pengembangan (Research and Development) $R \& D)$. Bandung : CV. Alfabeta.

2019. Metode Penelitian dan Pengembangan (Research and Development/ $R \&$ D). Bandung : CV. Alfabeta.

Dhammapada. (2021). Jakarta: Yayasan Dana Pendidikan Buddha Nalanda.

Widodo, A. (2020). Nilai budaya ritual Perang Topat sebagai sumber pembelajaran IPS berbasis kearifan lokal di sekolah dasar. Gulawentah:Jurnal Studi Sosial, 5(1), 1. doi: 10.25273/gulawentah.v5i1.6359

Yasa, I. M. A. (2013). Upacara Perang Topat di Pura Lingsar Kecamatan Lingsar Kabupaten Lombok Barat (Kajian Pendidikan Agama Hindu). Journal of Chemical Information and Modeling, 53(9), 1689-1699. 